\title{
PROPERTIES OF FLUX-GROWN CORDIERITE \\ SINGLE CRYSTALS
}

\author{
A THESIS \\ Presented to \\ The Faculty of the Division of Graduate Studies \\ By \\ Jae Do Lee
}

\author{
In Partial Fullment \\ of the Requirements for the Degree \\ Master of Science in Ceramic Engineering
}

\author{
Georgia Institute of Technology \\ August, 1975
}




\section{PROPERTIES OF FLUX-GROWN CORDIERITE \\ SINGLE CRYSTALS}

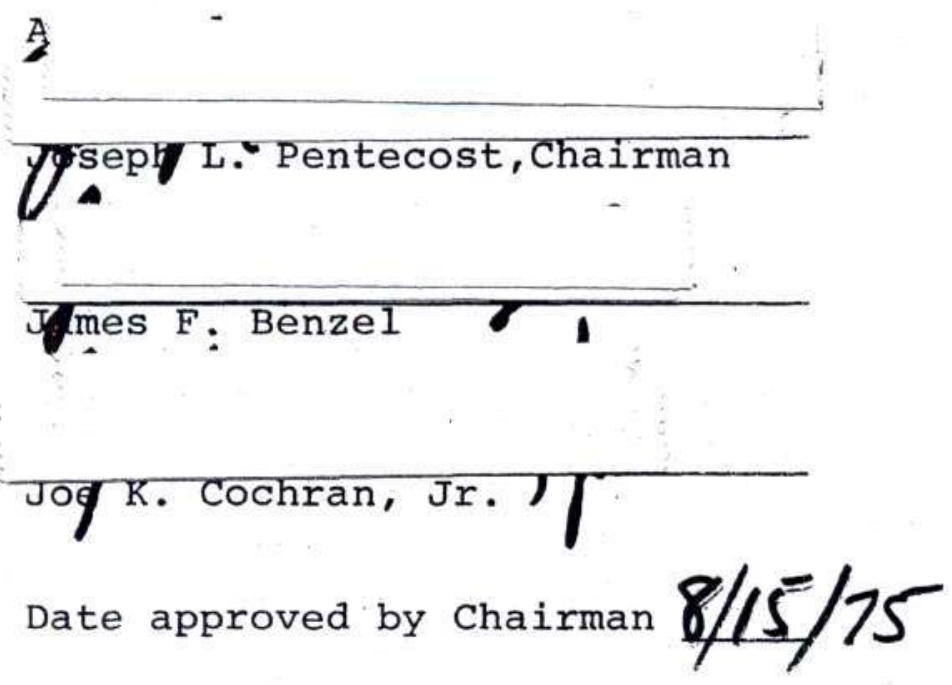


ACKNOWLEDGEMENTS

I am deeply indebted to $\mathrm{Dr}$. J. I. Pentecost for his advice and help, not only concerning this work, but at every stage of my graduate studies. My appreciation is expressed to Dr. J. K. Cochran, Jr. for his interest and assistance in the research, and for serving on the reading committee. My appreciation is also expressed to Dr. J. F. Benzel for serving on the reading committee.

I wish to thank Coor's Spectrochemical Laboratory for the chemical analysis. I wish to thank Mr. T. Mackrovitch for his help through this work.

The endurance and assistance of my wife, Kyong In, are gratefully acknowledged. 
Page

ACKNOWLEDGEMENTS . . . . . . . . . . . . . . i i

LIST OF TABLES ............... . . . . . iv

LIST OF ILLUSTRATIONS. . . . . . . . . . . v v

SUMMARY ................... . . . vi

Chapter

I. INTRODUCTION . . . . . . . . . . . . 1

II. REVIEW OF THE LITERATURE . . . . . . . . . 2

Cordierite

Crystal Structure

Properties of Cordierite Bodies

Crystal Growth

III. PROCEDURE . . . . . . . . . . . . 10

Flux Selection

Crystal Growth

Identification of Structural Form

Thermal Expansion Measurement

IV. RESULTS AND DISCUSSION . . . . . . . . .

Flux Selection

Crystal Growth

Structural Form of the Crystal

Optical Properties

Thermal Properties

V. SUMMARY AND CONCLUSIONS . . . . . . . . .

VI. RECOMMENDATIONS . . . . . . . . . . . 38 APPENDICES ........................ 39

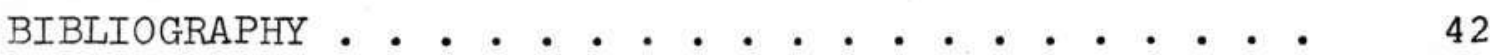


Table

Page

1. Linear Thermal Expansion Coefficients of Cordierite from Orijaervi ............... 6

2. Starting Composition and Results............. 15

3. Comparison of Refractive Indices of Cordierite Polymorphs .................... 25

4. Thermal Expansion of Cordierite: A-axis vs. Temperature .................. 26

5. Thermal Contraction of Cordierite: C-axis vs. Temperature $\ldots \ldots \ldots \ldots \ldots \ldots \ldots \ldots . . \ldots \ldots$

6. Axial, Volume and Calculated Bulk Thermal Expansion of Cordierite ............. 31

7. Thermal Contraction of Orthorhombic Cordierite: C-axis vs. Temperature ........... 34

8. Semiquantitative Spectrochemical Analysis on the Cordierite Single Crystals 
LIST OF ILLUSTRATIONS

Figure

Page

1. Flux-grown Cordierite Single Crystals . . . . 18

2. Optical Micrograph Showing Inclusions in Cordierite Single Crystal . . . . . .

3. Transmission Optical Micrographs Showing the Cloudy Region in Cordierite Single Crystal . . . . . . . . . . . . 20

4. Effect of Time on Width Index $(\mathrm{W}-1 / 3)$ at $1260^{\circ} \mathrm{C}$. . . . . . . . . 23

5. Comparison of Diffraction Pattern and Width Index for As-grown Cordierite and Cordierite Heated at $1260^{\circ} \mathrm{C}$. . . . . . 24

6. Thermal Expansion of Cordierite: Axial Expansions and Volume vs. Temperature . . . . 30

7. Thermal Expansion of Cordierite: Axial Expansions and Unit Cell Volume vso Temperature (after Fisher et. al.20) . . . . 33

8. Comparison of Thermal Contraction between Orthorhombic and Hexagonal Form of Cordierite... . . . . . . . . . 35

9. Thermal Expansion of Cordierite along the A-axis................. 40

10. Thermal Contraction of Cordierite along the C-axis................... 


\section{SUMMARY}

Cordierite single crystals up to $6 \mathrm{~mm}$ long were grown by a flux growth technique, and the anisotropic axial and unit cell volume thermal expansion of the crystals (hexagonal form) were determined using a dilatation interferometer. The expansion along the a-axis was nearly linear within the temperature range studied while the contraction along the c-axis was parabolic. The a-axis expansion was about $0.22 \%$ and the c-axis contraction was about $0.14 \%$ at $800^{\circ} \mathrm{C}$. The thermal behavior of the cordierite unit cell was similar to that of $\beta$-spodumene-silica solid solutions.

The c-axis contraction of the orthorhombic form of cordierite obtained by heating hexagonal crystals at $1260^{\circ} \mathrm{C}$ for 165 hours, was about 15\% greater than the hexagonal form. 
CHAPTER I

INTRODUCTION

Cordierite bodies represent a technically important class of compositions due to their low coefficients of thermal expansion and their high resistance to thermal shock. The coefficient of thermal expansion depends on the quantity of the cordierite phase developed and the nature of the impurities. The composition and processing of cordierite bodies has been studied extensively.

Due to the increasing usage of cordierite monolith as a catalyst support material, the intrinsic properties of cordierite $\left(2 \mathrm{MgO} \cdot 2 \mathrm{Al}_{2} \mathrm{O}_{3} \cdot 5 \mathrm{SiO}_{2}\right)$ has been studied to establish the bulk properties of the material. Several previous studies were performed on microcrystals devitrified from glass or from sintered bodies. The complexity of the phase relationships in the $\mathrm{MgO}-\mathrm{Al}_{2} \mathrm{O}_{3}-\mathrm{SiO}_{2}$ system, the incongruent melting point, the tendency for glass formation and rapid spontaneous nucleation of cordierite indicated that difficulties could be anticipated in growing single crystals of substantial size for further investigation.

The objectives of the present work were to prepare single crystals of cordierite and to determine the properties of these single crystals. 
CHAPTER II

REVIEW OF THE LITERATURE

Cordierite

Cordierite $\left(2 \mathrm{MgO}-2 \mathrm{Al}_{2} \mathrm{O}_{3}-5 \mathrm{SiO}_{2}\right)$ is a ternary compound in the $\mathrm{MgO}-\mathrm{Al}_{2} \mathrm{O}_{3}-\mathrm{SiO}_{2}$ system. ${ }^{1}$ It has a low coefficient of thermal expansion and chemical stability at moderate temperature so that it is used widely when low thermal expansion materials are required.

Natural cordierite is not known to occur in deposits of commercial value. However, snythetic cordierite has been developed using various raw materials.1,2,3

\section{Crystal Structure}

Through the first $\mathrm{x}$-ray crystallographic study of cordierite minerals, Gossner and Mussgnug ${ }^{4}$ concluded that it was homotypic with Beryl, $\mathrm{Be}_{3} \mathrm{Al}_{2} \mathrm{SiO}_{18}$, with the structrual formula $\left(\mathrm{Mg}_{2} \mathrm{Al}\right)^{\mathrm{IV}} \mathrm{Al}_{2} \mathrm{IV}-\left(\mathrm{AlSi}_{5}\right)^{\mathrm{IV}} \mathrm{O}_{18} \cdot \mathrm{Bragg}^{5}$ modified the structural formula to $\mathrm{Al}_{3}^{\mathrm{IV}} \mathrm{Mg}_{2}^{\mathrm{IV}}-\left(\mathrm{AlS}_{5}\right)^{\mathrm{IV}_{\mathrm{O}_{18}}}$. This relationship was confirmed by Takane and Takenchi ${ }^{6}$ and by Bystroem ${ }^{7}$ independently. Bystroem ${ }^{7}$ assigned a random distribution of one Al- and five Si- atoms to the six-membered ring which are joined by alumina tetrahedral and magnesia octahedron.

After discovering the ( $\beta$ ) form, and a metastable form, 
Karkhanavala and Humme ${ }^{8}$ classified three polymorphic cordierite forms; (1) a stable high-temperature ( $\alpha$ ) form obtained by solid state reaction between $1300^{\circ}$ to $1460^{\circ} \mathrm{C}$ or by crystallization of the glass between $1050^{\circ}$ and $1460^{\circ} \mathrm{C}$, a stable low-temperature $(\beta)$ form developed by hydrothermal treatment of glass, $\alpha$ or $\mu$ forms below $830^{\circ} \mathrm{C}$, and (3) a metastable low-temperature ( $\mu$ ) form developed by crystallization of glass between $800^{\circ}$ and $900^{\circ} \mathrm{C}$ for long period of time. Miyashiro et al, 9 found a new natural mineral, indialite, a polymorphic form of cordierite and proposed that Al and $\mathrm{Si}$ are disordered in the hexagonal form and ordered in orthorhombic form. This structure does not agree with the space group Cccm as reported by Takane and Takenchi ${ }^{3}$.

In 1957, Miyashiro ${ }^{10}$ proposed a time-temperature dependent structural series between hexagonal cordierite (indialite) and an orthorhombic form, perdistortional cordierite and discovered various degrees of orthorhombic deviation from hexagonal symmetry. This results in the splitting of certain $\mathrm{x}$-ray peaks and a decrease in the apparent intensity. The degree of deviation was characterized by a distortion index, $\Delta$, which is the angular distance between the peak with the higher $2 \theta$ value and the midpoint between the two peaks in $29^{\circ}$ and $30^{\circ}$.

Miyashiro's work has been confirmed by others 11,12 and is generally accepted. Miyashiro ${ }^{10}$ believed that the $(\alpha)$ form and $(\beta)$ form as described by Karkhanavala and Hummel ${ }^{8}$ 
were indialite and subdistortional cordierite respectively and the distortion index, $\Delta$, represented a measure of the $\mathrm{Al} / \mathrm{Si}$ order. Later, the alleged $\alpha-\beta$ transition was shown to be nonpolymorphic and due to variable amounts of water incorporated in the structure. 11,13

The distortion index is not only a function of the structural state of cordierite, but it is also influenced by its chemical composition. 11,14 Although Langer ${ }^{14}$ felt the distortion index did not represent a measure of the degree of $\mathrm{Al} / \mathrm{Si}$ order, it has been generally accepted that one Aland five si-cations in the ring are ordered in low cordierite, disordered in high cordierite and of intermediate order in the intermediate states. The ordering is thought to be a continuous process, its degree, and thus the degree of distortion from the hexagonal structure, being tied to a certain maximum.

The refinement of the structure of orthorhombic cordierite by $\mathrm{Gibbs}^{15}$ revealed a frame work completely ordered with regard to $\mathrm{Al}$ and $\mathrm{Si}$ cations, but he proved that the hexagonal symmetry of high cordierite was caused by at least partial disorder of $\mathrm{Al}$ and $\mathrm{Si}$ atoms.

A metastable phase $(\mu)$ of cordierite composition, unclassified by Miyashiro ${ }^{10}$, was found by Schreyer and Schairer 11 to exhibit a "stuffed" high-quartz structure and was later confirmed by Langer and Schreyer ${ }^{14}$. This phase which was similar to high-eucryptite $\left(\mathrm{LiAlSiO}_{4}\right)$ disappeared upon heating 
at $980^{\circ} \mathrm{C}$ through a reconstructive transformation into highcordierite.

Properties of Cordierite Bodies

(a) Thermal Expansion

Hummel ${ }^{16}$ et al, found the linear expansion of coefficient in the range $25^{\circ}$ to $1000^{\circ} \mathrm{C}$ of $\alpha$-cordierite aggregates prepared by solid phase reaction to be about 20 $\times 10^{-7} /{ }^{\circ} \mathrm{C}$.

Beals \& $\operatorname{Cook}^{17}$ found the linear expansion coefficients of the $\mu$-cordierite aggregate in the range $25^{\circ}$ to $870^{\circ} \mathrm{C}$ to be $47.2 \times 10^{-7} /{ }^{\circ} \mathrm{C}$ whereas that of the $\alpha$-cordierite aggregate in the range 25 to $1000^{\circ} \mathrm{C}$ was $24.7 \times 10^{-7} /{ }^{\circ} \mathrm{C}$. Beals and Cook $^{17}$ observed a close correlation between the cordierite content and thermal expansion behavior. For the bodies studied an increase in cordierite content resulted in a decrease in the coefficient expansion. The linear thermal expansion coefficient observed was $9.8 \times 10^{-7} / 0^{\circ} \mathrm{C}$ for a $90 \%$ cordierite body for the range $20^{\circ}$ to $300^{\circ} \mathrm{C}$.

The axial linear expansion coefficients of a mineral cordierite was measured by Gugel and Vogel. ${ }^{18}$ The observed axial expansions were anisotropic and are summarized in Table 1. They inferred that the expansion is also influenced by existing impurities. 
Table 1. Linear Thermal Expansion Coefficient of Cordierite from orijaervi ${ }^{(18)}\left(10^{-6} /{ }^{\circ} \mathrm{C}\right)$

\begin{tabular}{lllll}
\hline $\begin{array}{l}\text { Temperature } \\
\text { range }\left({ }^{\circ} \mathrm{C}\right)\end{array}$ & $\alpha a$ & $\alpha b$ & $\alpha \mathrm{c}$ & $\alpha^{*}$ \\
\hline 20 to 100 & 2.05 & 0.80 & -0.45 & 0.80 \\
20 to 200 & 2.55 & 1.16 & \pm 0 & 1.24 \\
20 to 400 & 2.76 & 1.60 & 0.31 & 1.56 \\
20 to 600 & 3.05 & 1.91 & 0.72 & 1.88 \\
20 to 800 & 3.22 & 2.20 & 0.91 & 2.10 \\
\hline
\end{tabular}

$$
\alpha *=\frac{\alpha(a+b+c)}{3}
$$

Sugiura and Kuroda ${ }^{19}$ determined the axial thermal expansion of hexagonal cordierite, devitrified at $950^{\circ} \mathrm{C}$ for 12 hours, by a high-temperature x-ray powder diffraction technique. The observed axial expansions showed that $a_{0}$ expanded while $c_{0}$ contracted sharply. The calculated average linear thermal expansion observed was negative up to 130$140^{\circ} \mathrm{C}$.

Fisher ${ }^{20}$ et al. also determined the axial and unit cell volume thermal expansion of hexagonal (high) cordierite by a high-temperature $\mathrm{x}$-ray powder diffraction technique. The observed axial expansions were anisotropic with the a-axis expanding by about $0.35 \%$ at $1200^{\circ} \mathrm{C}$. The initial c-axis contraction is about $0.15 \%$, but changes sign at about $400^{\circ} \mathrm{C}$, and still slightly negative at $1200^{\circ} \mathrm{C}$. 
Although the mechanism causing the anisotropy of thermal expansion is complex and not fully understood, continuous changes in bond angle and bond lengths as temperature changes are considered as the major factors producing the anistropic behavior. ${ }^{21}$

Anisotropic thermal expansions were observed in several structures which are all based upon coordination of polyhedra that are not close packed; $\beta$-quartz, $\beta$-eucryptite, 22 and $\beta$-spodumene-silica solid solution. 23

(b) Optical Properties

The mean refractive index of cordierite reflects both the compositional and structural variation. 11 Cordierite minerals exhibit refractive indices $\mathrm{N} \alpha=1.532, \mathrm{~N} \beta=1.536$ to 1.562 and $\mathrm{N} \gamma=1.539$ to 1.570 and are biaxial negative. ${ }^{24}$ For hexagonal $(\alpha)$ form, $N \alpha$ was 1.521 to 1.524 and $N \gamma=1.526$ to 1.528 and were uniaxial negative. ${ }^{8}$ For the $(B)$ form, $N \alpha=1.537$ and $N \gamma=1.541$ and that of $(\mu)$ form is $1.546 .^{11}$

\section{Crystal Growth}

The large number of techniques of crystal growing have been developed. Among them, the flux growing technique has been used to grow the single crystal of poly-component compounds, especially those which melt incongruently.

A common technique is to dissolve sufficient amounts of the components required to form the crystal in a flux at a temperature slightly above the saturation temperature and 
then to slowly cool the melt. Growth is on spontaneously formed nuclei. In flux growing methods, the choice of a solvent is the greatest experimental difficulty. Impurity control may also be difficult if flux components are soluble in the grown crystals. The requirements of a good solvent are: 25

1. That the solute is the stable solid phase at the growth condition.

2. High solute solubility $(10-50 \%)$.

3. An appreciable temperature coefficient of solubility $\left(1 \mathrm{Wt} \% / 10^{\circ} \mathrm{C}\right)$ so that slow cooling is practical (isothermal growth in a thermal gradient will relax this requirement, as will growth by flux evaporation).

4. Low volatility (covered or welded crucibles will relax this requirement).

5. Unreactivity with container, mainly platinum.

6. Low solvent solubility in the grown crystals (a common ion between crystal and solvent is helpful in repressing solvent contamination).

7. Good-quality growth at reasonable rates in the solvent (usually growing-interface shape, growth rates, etc. are solvent dependent).

8. Low viscosity.

The complexity of the phase relationships in the Mgo$\mathrm{Al}_{2} \mathrm{O}_{3}-\mathrm{SiO}_{2}$ system, the incongruent melting point, the tendency for glass formation and rapid spontaneous nucleation of 
cordierite ${ }^{1,11}$ indicate that difficulties may be anticipated in growing single crystals of substantial size.

The following oxides $-\mathrm{V}_{2} \mathrm{O}_{5}, \mathrm{MoO}_{3}, \mathrm{LiO}, \mathrm{PbO}$ and their combinations were selected as possible fluxes. Selection was based on a previous investigation where beryl single crystals were grown $26,27,28,29$. Beryl is isostructured with cordierite and also melts incongruently. 
CHAPTER III

PROCEDURE

To determine a suitable flux for growing cordierite single crystals a number of trials were made. The nutrient materials used in these experiments were high purity cordierite glass powder (Glasrock Corporation). Fluxes were reagent grade chemicals.

A sample of a predetermined composition was mixed mechanically and loaded in a $50 \mathrm{ml}$ Pt crucible. The filled crucible was placed in a vertical tube furnace or box-type furnace. The tube furnace was designed to provide a $15^{\circ} \mathrm{C}$ or more thermal gradient between top and bottom of the melt in the $1100^{\circ}-1250^{\circ} \mathrm{C}$ range and was used for crystal growing by temperature gradient transfer methods. Nutrient material (undissolved) was transferred in solution from the hot area of the flux to the cooler area where crystals grew by spontaneous nucleation or on seeds added after the flux became saturated. Some flux evaporation also encouraged crystal growth.

The box furnace had a uniform temperature zone in which the crucible was placed and was used for the slow cooling experiments. All nutrients were dissolved initially and crystals formed due to spontaneous nucleation. A cooling 
rate of $6^{\circ} \mathrm{C}$ per hour was used. The maximum temperature was held for 6 hours to provide a homogeneous melt before cooling was started. After slow cooling to $950^{\circ} \mathrm{C}$, the remaining liquid was poured from the crucible and the crucible cooled to room temperature in air. The contents of the crucible were leached with hot $\mathrm{HNO}_{3}$ to separate the crystals from the residual flux. X-ray powder diffraction analysis was used for single crystal phase identification. From a number of these preliminary studies it was determined that $\mathrm{PbO}-\mathrm{V}_{2} \mathrm{O}_{5}$ was the best flux, and it was selected for all further crystal growth experiments.

\section{Crystal Growth}

In preliminary studies, undissolved cordierite powder was observed with many small cordierite single crystals. To determine a proper batch composition, mixtures consisting of $4,5,6$, and 7 grams of cordierite glass, 52 grams of $\mathrm{PbO}$ and 21 grams of $\mathrm{V}_{2} \mathrm{O}_{5}$ were prepared and crystals grown using the slow cooling technique. The batch containing 6 grams of cordierite produced the best single crystals.

The single crystals used to determine the properties of cordierite were grown as follows. The constituents were mixed until the batch looked uniformly brownish yellow and then loaded into a $50 \mathrm{ml}$ Pt crucible. The filled curcible was covered and placed in a silicon carbide resistance furnace. The furnace was controlled with a Series 80 Leeds and 
Northrup proportional controller and a curve follower. The crucible was heated to $1280^{\circ} \mathrm{C}$, held for 6 hours, and then cooled to $950^{\circ} \mathrm{C}$. The remaining liquid was decanted from the crucible, and the crucible replaced in the furnace to cool to room temperature at the natural cooling rate. No seed crystals were used.

\section{Identification of Structural Form}

The structural form of the cordierite crystals grown were identified by $\mathrm{x}$-ray diffraction analysis.

To determine the structural form, single crystals $1 \mathrm{~mm}$ or over in size were selected and leached with hot nitric acid and then ground to -200 mesh. The powder was heated for various times up to 195 hours at $1260^{\circ} \mathrm{C} \pm_{-5}^{\circ}$ in a silicon carbide resistance furnace. The furnace was controlled with a proportional current controller and a Data-Trak programmer. The sample was air cooled at the end of the desired time period. The sample was reground to -200 mesh. Analysis was performed using a Phillips x-ray diffractometer with Cuk radiation $(45 \mathrm{KV}$ and $20 \mathrm{ma})$. The goniometer was scanned between $29^{\circ}$ and $30^{\circ} 2 \theta$ at $1 / 8^{\circ}$ per minute. The width index, $\mathrm{W}-1 / 3$, which is the angular width of the peak at $1 / 3$ its height, was measured for each sample.

\section{Thermal Expansion Measurement}

Axial thermal expansion of the crystals was measured using a Gaertner 1-118-tl Dilatation Interferometer. The 
interferometer is used to measure the linear coefficient of expansion of specimens up to $10 \mathrm{~mm}$ long and is designed to permit observations at temperatures up $1000^{\circ} \mathrm{C}$. Measurements are made by placing three equal height specimens between the fused silica interferometer plates in the furnace, and noting through the viewing apparatus the movement of interference fringes as the temperature of the assembly was changed. Since each of the interference fringes represents a light path difference of one-half wave length, the change in vertical separation of the nearly parallel interferometer surfaces from one fringe to another is also one-half wavelength. Consequently, if a fringe moves past the reference point on the interferometer by a distance equal to the width of one fringe, the average length of the specimens has increased by one-half wavelength of mercury light $\left(2.73 \times 10^{-4} \mathrm{~mm}\right)$.

The total change in length, $\Delta \mathrm{L}$ is then given by

$$
\Delta \mathrm{L}=1 / 2 \mathrm{n} \lambda
$$

and the coefficient of thermal expansion for a given temperature range $\left(\mathrm{T}_{2}-\mathrm{T}_{1}\right)$ is given by $\alpha=\frac{\mathrm{n} \lambda}{2 \mathrm{~L}_{0}\left(\mathrm{~T}_{2}-\mathrm{T}_{1}\right)}$ where $\mathrm{n}$ is the number of fringes passing the reference point during a change from temperature $\mathrm{T}_{1}$ to temperature $\mathrm{T}_{2} ; \mathrm{L}$ is the height of the specimens, and $\lambda$ is the wavelength of the green radiation of the mercury spectrum. $(\lambda=0.0000546 \mathrm{~cm}$.$) .$ Thus, by measuring the number of fringes passing, expansion values of "a" and "c" can be determined from properly oriented 
samples, and hence the expansion coefficients. Well-formed crystals were carefully examined and the best crystals selected. Axial lengths were measured, and the three selected crystals were carefully polished to be equal in height and the height measured to within $\pm_{0.001}$ inches with a micrometer. The crystals were then placed between interferometer plates so that only a few interference fringes occurred. The number of fringes passing the reference point were measured through the viewing apparatus during heating up to $800^{\circ} \mathrm{C}$ at $1-5^{\circ} \mathrm{C}$ per minute. The temperature was measured to within $\pm 5^{\circ} \mathrm{C}$ using the output of cromel-alumel thermocouple. 
CHAPTER IV

\section{RESULTS AND DISCUSSION}

\section{Flux Selection}

To determine a suitable flux for growing cordierite single crystals a number of trials were made. Table 2 lists the starting compositions, growth conditions, and type crystals grown.

Table 2. Starting Composition and Results

\begin{tabular}{|c|c|c|c|}
\hline Starting & & Growth & Crystals \\
\hline Compositio & & Conditions & Produced \\
\hline $\mathrm{MoO}_{3}$ & $47.9(\mathrm{Gm})$ & $1160^{\circ} \mathrm{C}-85 \mathrm{Hrs}$. & Spodumene \\
\hline $\mathrm{Li}_{2} \mathrm{CO}_{3}$ & 12.3 & & \\
\hline Cordierite & 5.0 & & \\
\hline $\mathrm{V}_{2} \mathrm{O}_{5}$ & 70.0 & $1200^{\circ} \mathrm{C}-85 \mathrm{Hrs}$. & Cristobalite \\
\hline Cordierite & 7.0 & & \\
\hline $\mathrm{K}_{2} \mathrm{CO}_{3}$ & 27.6 & $1140^{\circ} \mathrm{C}-85 \mathrm{Hrs}$. & Potash Feldspar \\
\hline $\mathrm{MoO}_{3}$ & 57.5 & $1300^{\circ}-1030^{\circ} \mathrm{C}$ @ $6^{\circ} / \mathrm{hr}$ & \\
\hline Cordierite & 8.0 & & \\
\hline $\mathrm{V}_{2} \mathrm{O}_{5}$ & 21.0 & & \\
\hline $\mathrm{PbO}$ & 52.0 & $1250^{\circ}-950^{\circ} \mathrm{C}$ a $6^{\circ} \mathrm{C} / \mathrm{hr}$ & Cordierite \\
\hline Cordierite & 7.0 & & \\
\hline
\end{tabular}


When $\mathrm{LiO}_{-} \mathrm{MOO}_{3}$ or $\mathrm{K}_{2} \mathrm{O}-\mathrm{MOO}_{3}$ were used as flux, small crystals of spodumene or potash feldspar rather than cordierite crystallized respectively. It appears that spodumene and potash feldspar are much less soluble in these flux melts than cordierite.

When $\mathrm{V}_{2} \mathrm{O}_{5}$ is used as the flux, small crystal and whiskers of cristobalite were grown. Similar results were reported by Grodkiewiz and et al. ${ }^{30}$ They also reported the formation of a compound between the acidic oxide $\left(\mathrm{V}_{2} \mathrm{O}_{5}\right)$ and $\mathrm{Mg}^{++}$or $\mathrm{Ca}^{++}$silicate. In order to reduce the reactivity of $\mathrm{V}_{2} \mathrm{O}_{5}$ it was decided to employ $\mathrm{V}_{2} \mathrm{O}_{5} \cdot \mathrm{PbO}$ mixtures as fluxes. Another advantage of adding $\mathrm{V}_{2} \mathrm{O}_{5}$ to $\mathrm{PbO}$ was to greatly reduce the degree to which platinum is attached so that prolonged experiments may be conducted, even at high temperature (over $\left.1350^{\circ} \mathrm{C}\right) \cdot{ }^{31}$

Mixtures of 21 grams of $\mathrm{V}_{2} \mathrm{O}_{5}, 52$ grams of $\mathrm{PbO}$, and 7 grams of cordierite glass were placed in platinum curcibles. The filled crucibles were heated to $1250^{\circ} \mathrm{C}$, held for 6 hours, and then cooled to $950^{\circ} \mathrm{C}$ at $6^{\circ} \mathrm{C}$ per hours. Many small (1-3 mm) cordierite crystals were obtained from the melts. As a result, combinations of $\mathrm{PbO}$ and $\mathrm{V}_{2} \mathrm{O}_{5}$ were utilized to grow cordierite single crystal.

\section{Crystal Growth}

In a series of experiments with different cordierite contents, little or no crystalline cordierite was obtained 
from flux mixtures containing less than 4 grams of cordierite, whereas a large number of tiny single crystals and undissolved cordierite was observed when cordierite contents of 6 grams or more were utilized. From the above results, the solubility of cordierite in the solvent was estimated to be approximately $5 \mathrm{Wt} \%$ at $950^{\circ} \mathrm{C}$ and $8 \mathrm{Wt} \%$ at $1250^{\circ} \mathrm{C}$.

Well-formed cordierite single crystals were grown from the standard solvent composition which contained $7.5 \mathrm{Wt} \%$ cordierite. The mixture was heated in a Pt crucible to $1280^{\circ} \mathrm{C}$, held for 6 hours, and was then cooled at $950^{\circ} \mathrm{C}$ at $6{ }^{\circ} \mathrm{C}$ per hour. The remaining melt was decanted from the crucible, and the crucible replaced in the furnace to cool to room temperature at the natural cooling rate. No seed crystals were used and spontaneous nucleation provided a number of well-formed crystals floating on or near the flux surface. The crystals were leached with hot nitric acid to remove the residual flux and yielded cordierite single crystals up to $6 \mathrm{~mm}$ long, and of distinct hexagonal prism morphology as shown in Figure 1. Most of the large crystals grown were not transparent and were uniformly olive or gold in color. Some inclusions which are related to internal cracks were observed (Figure 2). As observed in ice crystals with pores, the boundary between transparent regions and the cloudy regions can be observed (Figure 3).

The density of cordierite single crystals was found to vary between 2.55 to $2.75 \mathrm{Gms} / \mathrm{Cm}^{3}$. Measurements were 


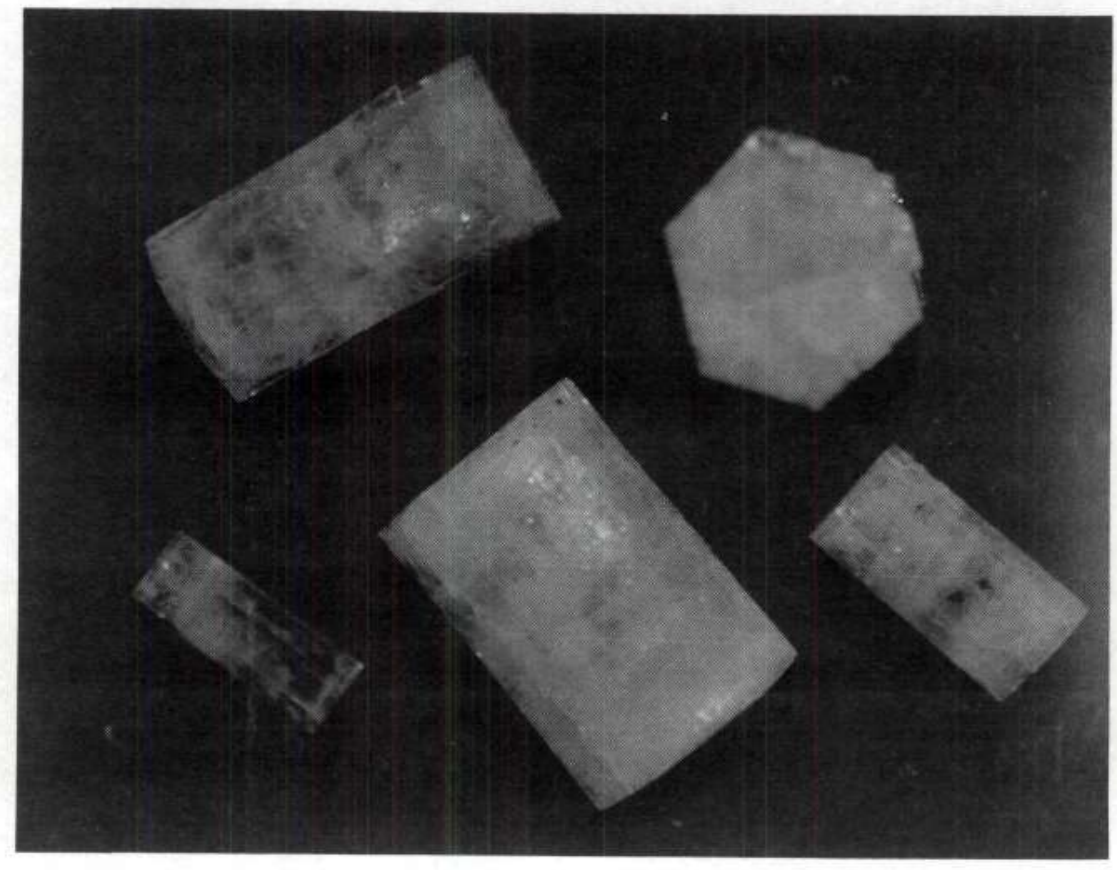

Fig. 1. Flux Grown Cordierite Single Crystals (xl6) 


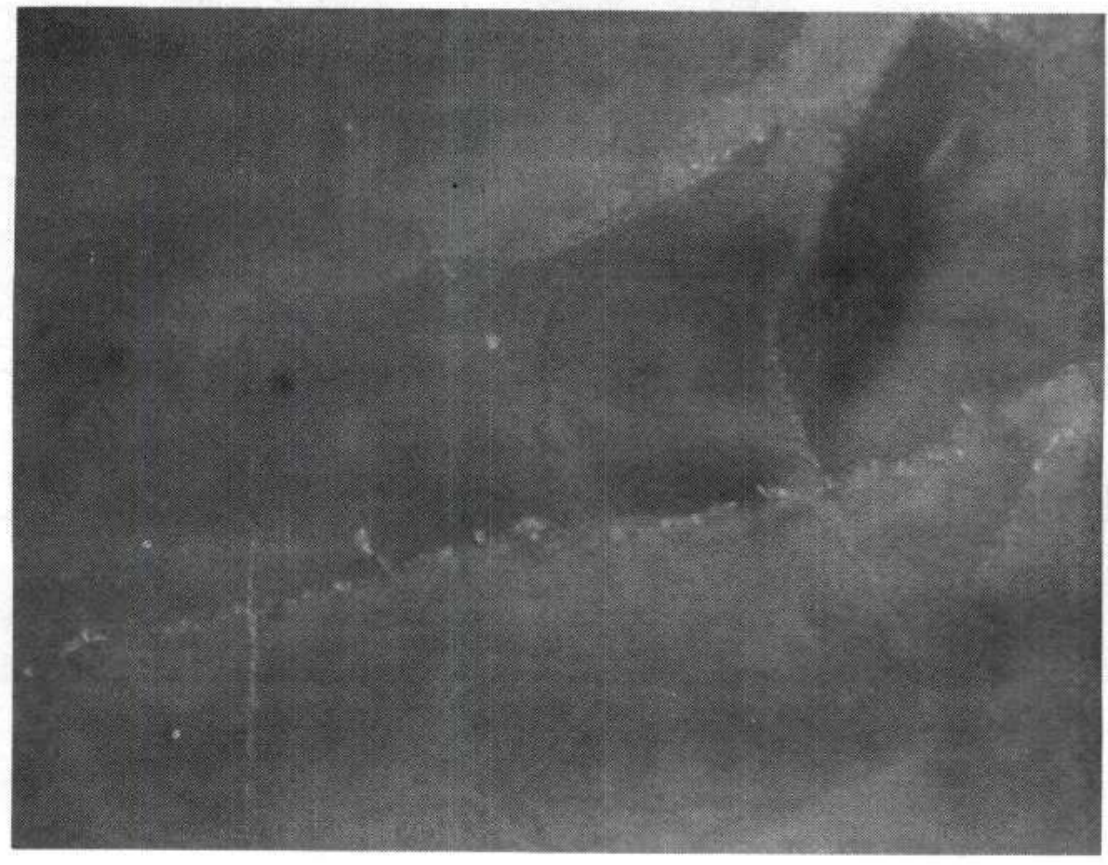

Fig. 2. Optical Micrograph Showing Inclusions In Cordierite Single Crystals ( $\mathrm{x} 200$ ) 


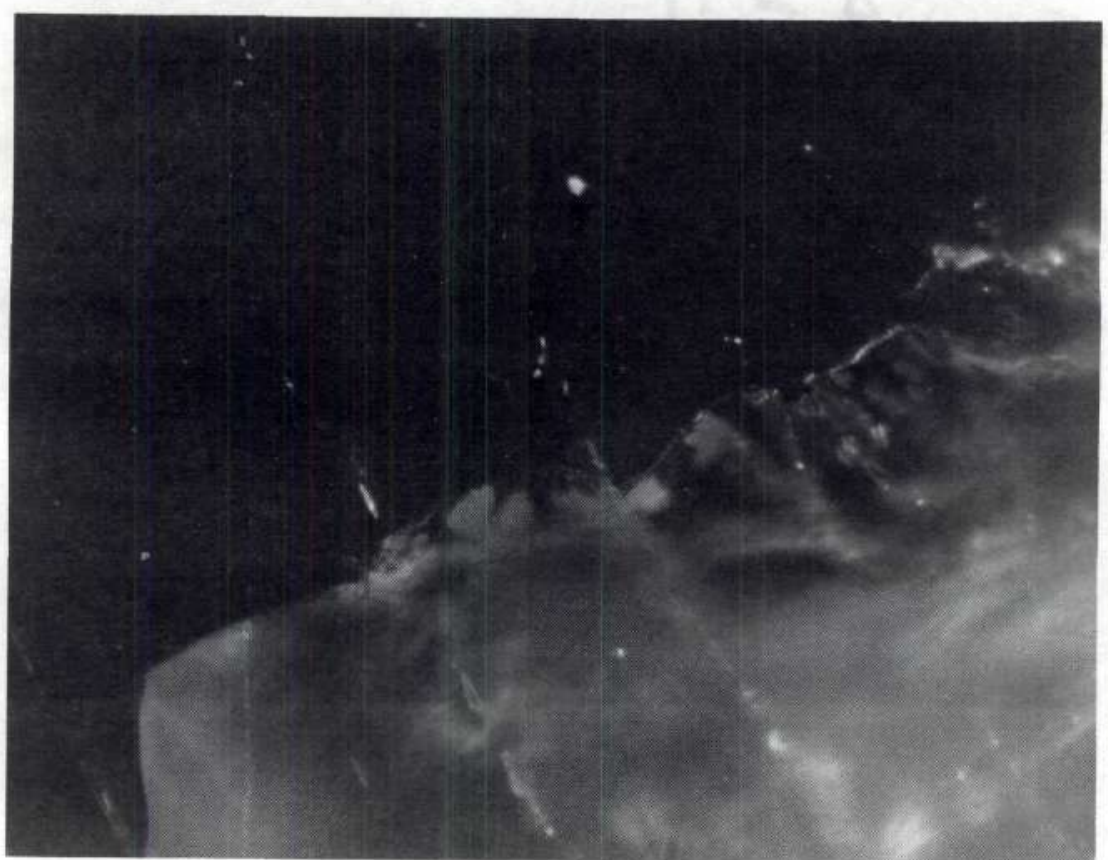

Fig. 3. Transmission Optical Micrograph Showing Cloudy Region In Cordierite Single Crystals (x600) 
made by adjusting the density of a mixture of 5-tetrabromoethane and 1-bromonaphtalene until the crystals were suspended by measuring the density of the liquid pycnometrically. These values are high compared with the calculated x-ray density of $2.51 \mathrm{Gm} / \mathrm{Cm}^{3}$. Semi-quantitative spectrochemical analysis were performed (Coor's Spectrochemical Laboratory) on crystals to determine the amount of trace elements and showed flux impurities, mainly $\mathrm{Pb}-0.5 \mathrm{Wt} \%$ and $\mathrm{V}-0.1$ Wt: (Appendix A) .

$\mathrm{A} \mathrm{Pb}$ content as little as $0.5 \mathrm{Wt}$ \% would be sufficient to explain the difference between measured density $(2.565$ $\left.\mathrm{Gms} / \mathrm{Cm}^{3}\right)$ and $\mathrm{x}$-ray density $\left(2.510 \mathrm{Gms} / \mathrm{Cm}^{3}\right)$ assuming the impurity is present as inclusions.

Wood ${ }^{32}$ et al. reported $\mathrm{v}^{3+}$ substituted in $\mathrm{Al}^{3+}$ sites in colored green beryl crystals. The olive color of the crystals suggests that some aluminum may have been replaced by vanadium cations from the flux during crystal growing. Some tan or olive color frequently noted in polycrystalline, high purity cordierite also where small amounts of iorn are present.

From the chemical analysis, the measured density, and the visual observations of inclusions and color, we can conclude that the majority of the inclusions are $\mathrm{PbO}$ and $\mathrm{V}_{2} \mathrm{O}_{3}$ and these impurities are the reason for the color and cloudiness of the crystals. 


\section{Structural Form of the Crystal}

All as-grown cordierite crystals were clearly hexagonal as determined from $x$-ray measurements. After heattreating at $1260^{\circ} \mathrm{C}$, the width index, w-1/3, increased with time as cordierite transformed from the initial hexagonal lattice to the orthorhombic form (Figure 4). The diffractometer traces, Figure 5, showed a reduction in peak height and broadening of the cordierite peak (curve B) after 165 hours of heat treatment at $1260^{\circ} \mathrm{C}$.

The as-grown cordierite single crystals are hexagonal cordierite with no evidence of splitting or broadening of the (211) peak between $29^{\circ}$ and $30^{\circ} 2 \theta$ for $\mathrm{Cu} K \alpha$ radiation (A curve in Figure 5). Although cordierite structures are timetemperature dependent, the hexagonal form commonly develops at temperature below the indialite stability range as a result of rapid crystal growth. ${ }^{12}$

\section{Optical Properties}

The refractive indices were measured petrographically on small transparent crystals. The size of the crystals used were between 20 and 40 mesh. The cordierite single crystals had refractive indices $N_{\varepsilon}=1.520-1.522$ and $\mathrm{N} \omega=1.526$ and were uniaxial negative. In Table 3 the measured optical properties are compared with those of the cordierite polymorhps. ${ }^{5}$ 


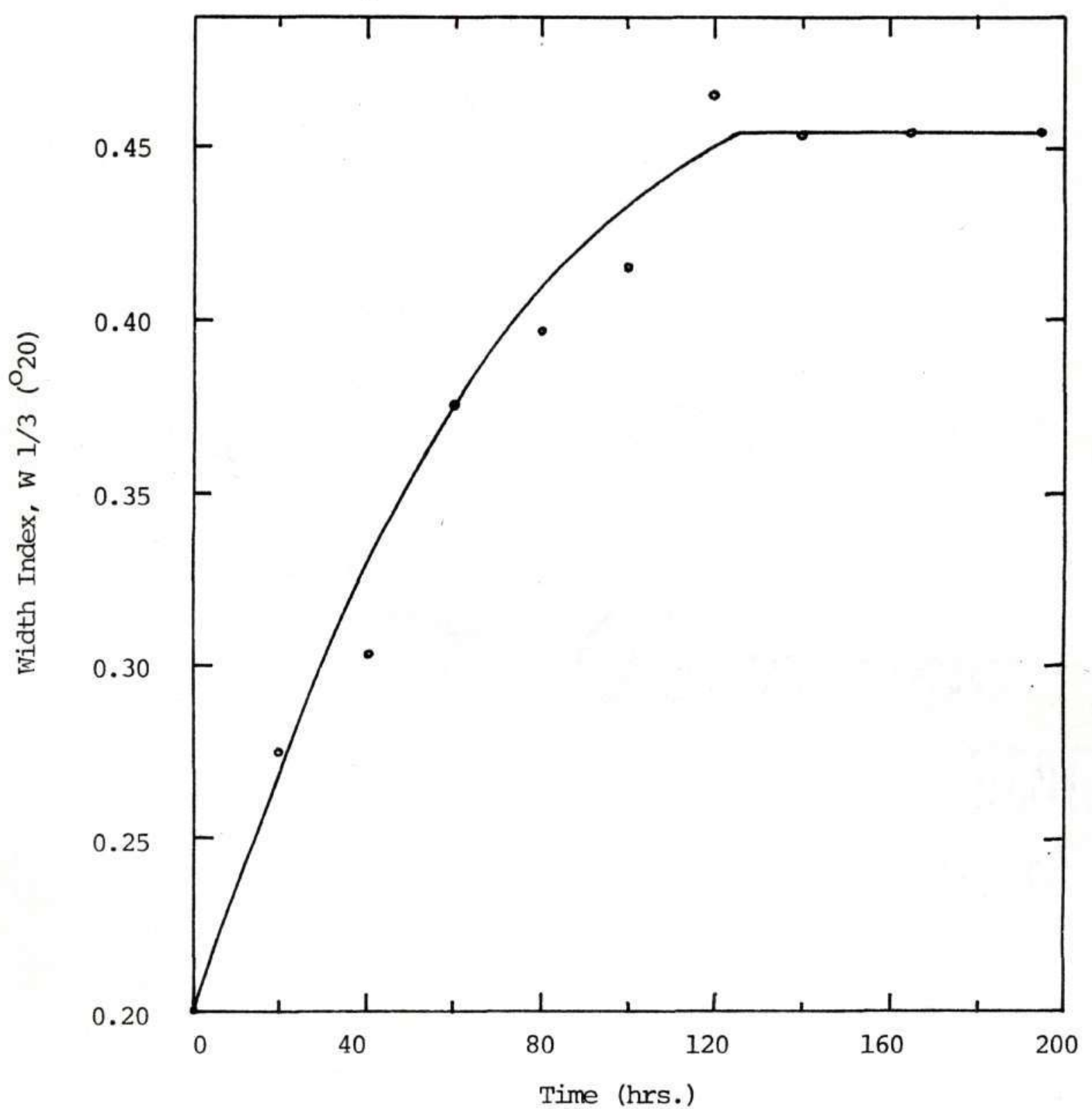

Fig. 4 Effect of Time on Width Index (W 1/3) at $1260^{\circ} \mathrm{C}$ 


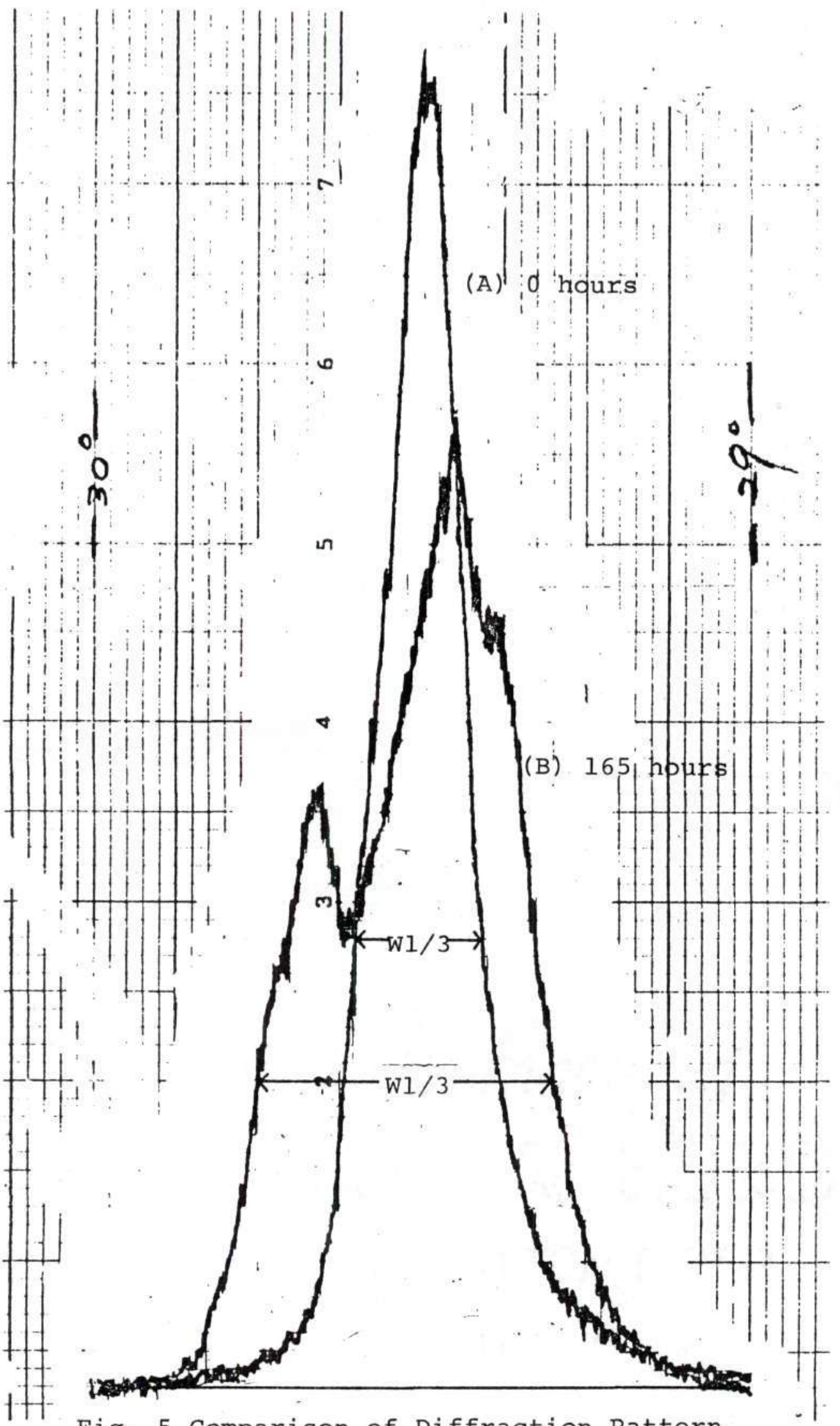

Fig. 5 Comparison of Diffraction Pattern and width Index for as-grown cordierite and Cordierite Heated at $1260^{\circ} \mathrm{C}$ 
Table 3. Comparison Refractive Indices of The Cordierite Polymorphs

\begin{tabular}{clll}
\hline Form & $\mathrm{n} \alpha$ & $\mathrm{n} \gamma$ \\
$\alpha$ & $1.521-1.524$ & $1.526-1.528(-)$ uniaxial \\
$\beta$ & 1.537 & 1.541 & \\
$\mu$ & 1.546 & & $(-)$ uniaxial \\
Measured & $1.520-1.522$ & 1.526 & \\
\hline
\end{tabular}

Thermal Expansion Properties

The changes in length of the a-axis and c-axis with changes in temperature for different specimens are shown and the calculated anisotropic thermal expansion along the cordierite crystal axes, $a_{0}$ and $c_{0^{\prime}}$ are summarized in Table 4 and 5, and are shown graphically in Figure 6 . The starting point of each run in Table 4 and 5 are different since the position of fringes of each run initially did not match the reference point in interferometer plate. The plot in Figure 6 was made by shifting each curve to match the starting points of each run. (Appendix B and C) It is obvious the same results were observed from various runs. The volume expansion coefficient of the hexagonal unit cell is $2 \alpha a+\alpha c$ and the average linear expansion coefficient of the lattice is $\frac{2 \alpha a+\alpha c}{3}$. The above results which represent the thermal expansion along the crystal axes in percent were used to calculate the change in volume of the unit cell and 
Table 4. Thermal Expansion of Cordierite:

A-axis vs. Temperature
a) Run \#1
$L_{0}=0.0648 \mathrm{~cm}$

\begin{tabular}{|c|c|c|c|}
\hline $\begin{array}{c}\text { Fringe No. } \\
n\end{array}$ & $\begin{array}{l}\text { Temp. } \\
\left({ }^{\circ} \mathrm{C}\right)\end{array}$ & $\begin{array}{l}\text { Measured } \\
\text { Expansion } \\
\Delta \mathrm{L}^{\star} \times 10^{-4} \mathrm{Cm}\end{array}$ & $\begin{array}{l}\text { of Expansion } \\
\Delta \mathrm{L} / \mathrm{L}_{\circ}(\%)\end{array}$ \\
\hline 0 & 80 & - & - \\
\hline 1 & 280 & 0.273 & 0.042 \\
\hline 2 & 420 & 0.546 & 0.084 \\
\hline 3 & 540 & 0.819 & 0.125 \\
\hline 4 & 660 & 1.092 & 0.169 \\
\hline 5 & 780 & 1.365 & 0.211 \\
\hline
\end{tabular}

$\star \Delta \mathrm{L}=1 / 2 \mathrm{n} \lambda \quad \lambda=0.0000546 \mathrm{Cm}$

b) Run \#2

$\mathrm{L}_{\mathrm{o}}=0.1230 \mathrm{~cm}$

\begin{tabular}{|c|c|c|c|}
\hline $\begin{array}{c}\text { Fringe No. } \\
\mathrm{n}\end{array}$ & $\begin{array}{l}\text { Temp. } \\
\left({ }^{\mathrm{O}} \mathrm{C}\right)\end{array}$ & $\begin{array}{l}\text { Measured } \\
\text { Expansion } \\
\Delta \mathrm{L}^{\star} \times 10^{-4} \mathrm{Cm}\end{array}$ & $\begin{array}{l}\text { \% of Expansion } \\
\Delta \mathrm{L} / \mathrm{L}_{\circ}(\%)\end{array}$ \\
\hline 0 & 50 & - & - \\
\hline 1 & 180 & 0.273 & 0.022 \\
\hline 2 & 280 & 0.546 & 0.044 \\
\hline 3 & 370 & 0.819 & 0.067 \\
\hline 4 & 445 & 1.092 & 0.089 \\
\hline 5 & 510 & 1.365 & 0.111 \\
\hline 6 & 575 & 1.638 & 0.133 \\
\hline
\end{tabular}


Table 4 - Run \#2 (Continued)

\begin{tabular}{rrrr}
7 & 635 & 1.011 & 0.155 \\
8 & 695 & 2.184 & 0.178 \\
9 & 755 & 2.457 & 0.200 \\
10 & 810 & 2.730 & 0.222 \\
\hline
\end{tabular}

Table 5. Thermal Contraction of Cordierite: C-axis vs.

Temperature
a) Run \#1
$\mathrm{L}_{\mathrm{O}}=0.1613 \mathrm{Cm}$

\begin{tabular}{cccc}
\hline $\begin{array}{c}\text { Fringe } \\
\mathrm{n}\end{array}$ & $\begin{array}{c}\text { Temp. } \\
\left({ }^{\circ} \mathrm{C}\right)\end{array}$ & $\begin{array}{c}\text { Measured Contraction } \\
\Delta \mathrm{L} \times 10^{-4} \mathrm{Cm}\end{array}$ & $\begin{array}{c}\text { of } \\
\Delta \mathrm{L} / \mathrm{L}_{\mathrm{O}}(\mathrm{\circ})\end{array}$ \\
\hline 0 & 40 & - & - \\
1 & 85 & 0.273 & 0.017 \\
2 & 135 & 0.546 & 0.034 \\
3 & 195 & 0.819 & 0.051 \\
4 & 260 & 1.092 & 0.068 \\
5 & 350 & 1.365 & 0.085 \\
6 & 455 & 1.638 & 0.102 \\
7 & 580 & 1.911 & 0.118 \\
8 & 735 & 2.184 & 0.135 \\
\hline
\end{tabular}


Table 5 (Continued)

b) Run \#2

$\mathrm{L}_{\mathrm{o}}=0.2273 \mathrm{~cm}$

\begin{tabular}{|c|c|c|c|}
\hline$\underset{\mathrm{n}}{\operatorname{Fringe}}$ No. & $\begin{array}{l}\text { Temp. } \\
\left({ }^{\circ} \mathrm{C}\right)\end{array}$ & $\begin{array}{l}\text { Measured Contraction } \\
\Delta \mathrm{L} \times 10^{-4} \mathrm{Cm}\end{array}$ & $\begin{array}{l}\text { of Contraction } \\
\Delta \mathrm{L} / \mathrm{L}_{\mathrm{o}}(\mathrm{o})\end{array}$ \\
\hline 0 & 30 & - & - \\
\hline 1 & 65 & 0.273 & 0.012 \\
\hline 2 & 95 & 0.546 & 0.024 \\
\hline 3 & 130 & 0.819 & 0.036 \\
\hline 4 & 170 & 1.092 & 0.048 \\
\hline 5 & 215 & 1.365 & 0.060 \\
\hline 6 & 275 & 1.638 & 0.072 \\
\hline 7 & 340 & 1.911 & 0.084 \\
\hline 8 & 410 & 2.184 & 0.096 \\
\hline 9 & 485 & 2.457 & 0.108 \\
\hline 10 & 580 & 2.730 & 0.120 \\
\hline 11 & 695 & 3.003 & 0.132 \\
\hline 11.5 & 775 & 3.140 & 0.138 \\
\hline
\end{tabular}


Table 5 (Continued)
c) Run \#3
$I_{O}=0.1397 \mathrm{~cm}$

\begin{tabular}{|c|c|c|c|}
\hline $\begin{array}{c}\text { Fringe No. } \\
n\end{array}$ & $\begin{array}{l}\text { Temp. } \\
\left({ }^{\mathrm{O}} \mathrm{C}\right)\end{array}$ & $\begin{array}{l}\text { Measured Contraction } \\
\qquad \Delta \mathrm{I} \times 10^{-4} \mathrm{Cm}\end{array}$ & $\begin{array}{c}\% \text { of Contraction } \\
\Delta \mathrm{L} / \mathrm{L}_{0}(\%)\end{array}$ \\
\hline 0 & 20 & - & - \\
\hline 1 & 80 & 0.273 & 0.020 \\
\hline 2 & 145 & 0.546 & 0.039 \\
\hline 3 & 220 & 0.819 & 0.059 \\
\hline 4 & 325 & 1.092 & 0.078 \\
\hline 5 & 445 & 1.365 & 0.980 \\
\hline 6 & 630 & 1.638 & 0.117 \\
\hline 7 & 850 & 1.911 & 0.137 \\
\hline
\end{tabular}




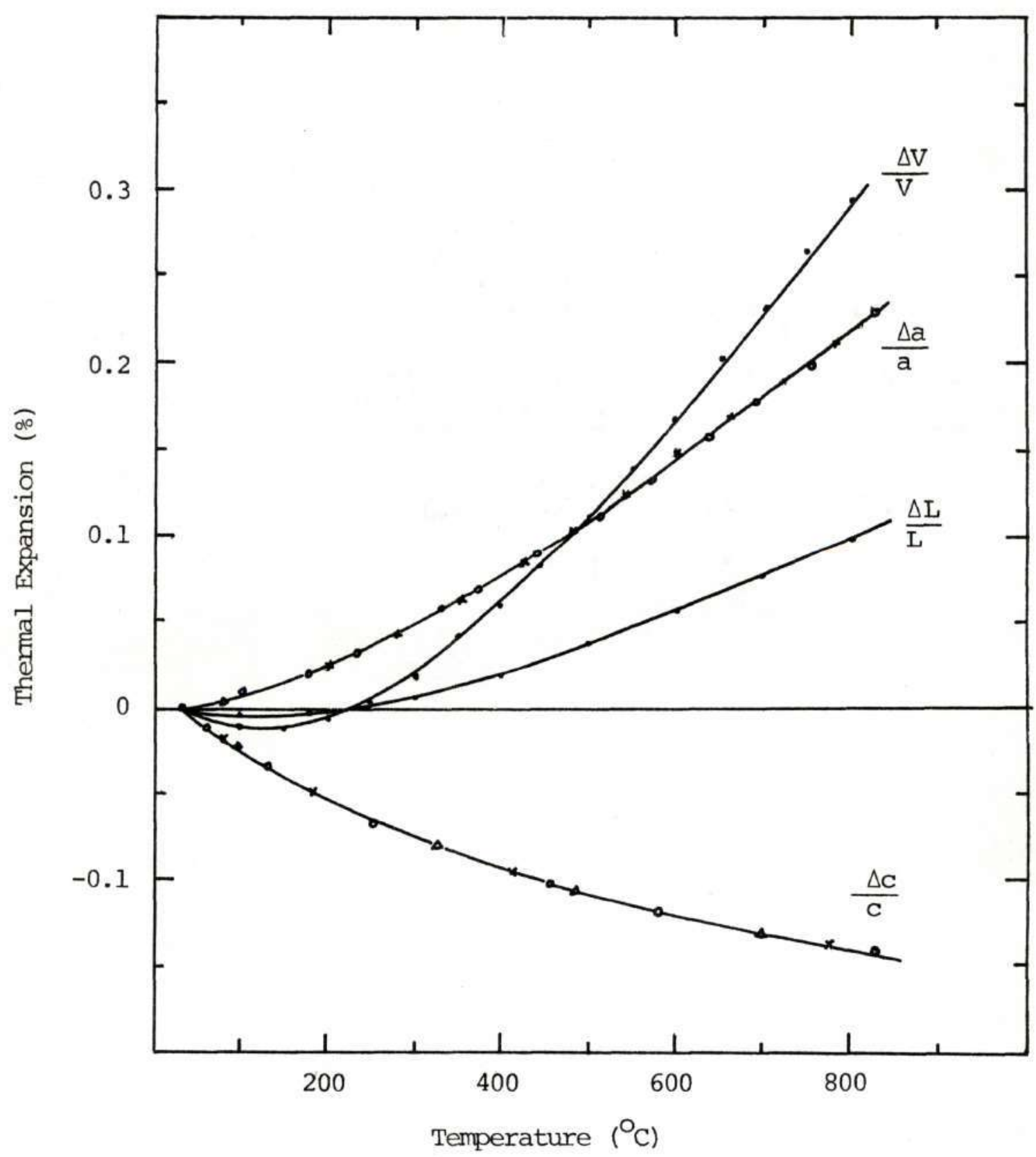

Fig. 6 Thermal Expansion of Cordierite: Axial Expansions and Volume vs. Temperature 
the bulk thermal expansion of cordierite. The results are also plotted in Figure 6 and summarized in Table 6 .

Table 6. Axial, Volume and Calculated Bulk Thermal Exapansion of Cordierite (ppm)

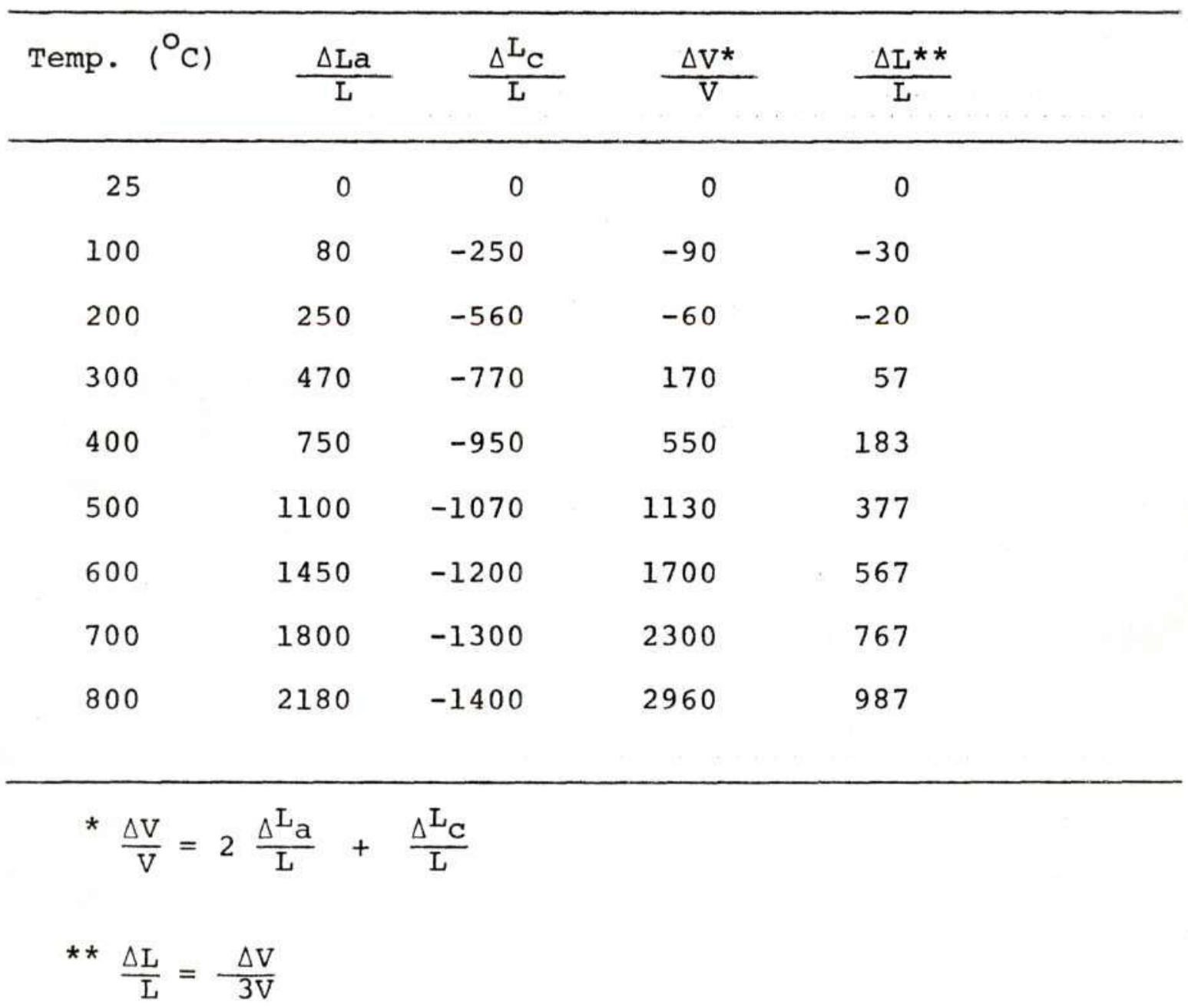

The a-axis expands continuously as temperature increases, within the range studied, while the c-axis contracts continuously as temperature increases, similar to $\beta$-spodumenesilica solid solution, except that for spodumene, the axes are reversed. 
Fisher et al. ${ }^{20}$ determined the axial expansion of polycrystalline cordierite powder by high temperature x-ray diffraction. From these measurements, the c-axis expansion was shown to have an inversion point, Figure 7. The reason for this difference is not known at this time, but could be due to mechanical constraints present in the polycrystalline material used by Fisher. As can be seen in Figure 7, the volume expansion agrees well with that reported by Fisher.

The difference in c-axis thermal contraction of hexagonal and orthorhombic cordierite were determined and the results are summarized in Table 7 and are shown graphically in Figure 8. This data was obtained using the same sample before and after heat treatment at $1260^{\circ} \mathrm{C}$ for 165 hours. From Figure 8 , it can be seen that the thermal contraction increases slightly as the hexagonal form transformed to the orthorhombic form. Similar measurements were not made on the $\mathrm{a}-\mathrm{b}$ axes due to inadequate knowledge of the crystal orientation after transformation to the orthorhombic form. Since the expansion is dependent on the degree of deviation from hexagonal, this may be another reason for the discrepancy between this work and Fisher et al. ${ }^{20}$ on the $\Delta \mathbf{c} / \mathrm{c}$ expansion. The mechanism causing the anisotropy of thermal expansion is complex and not fully understood. Continuous alternations of bond angles and interatomic distances which do not generate new symmetry elements are major factors associated with anisotropic thermal behavior. It is difficult 


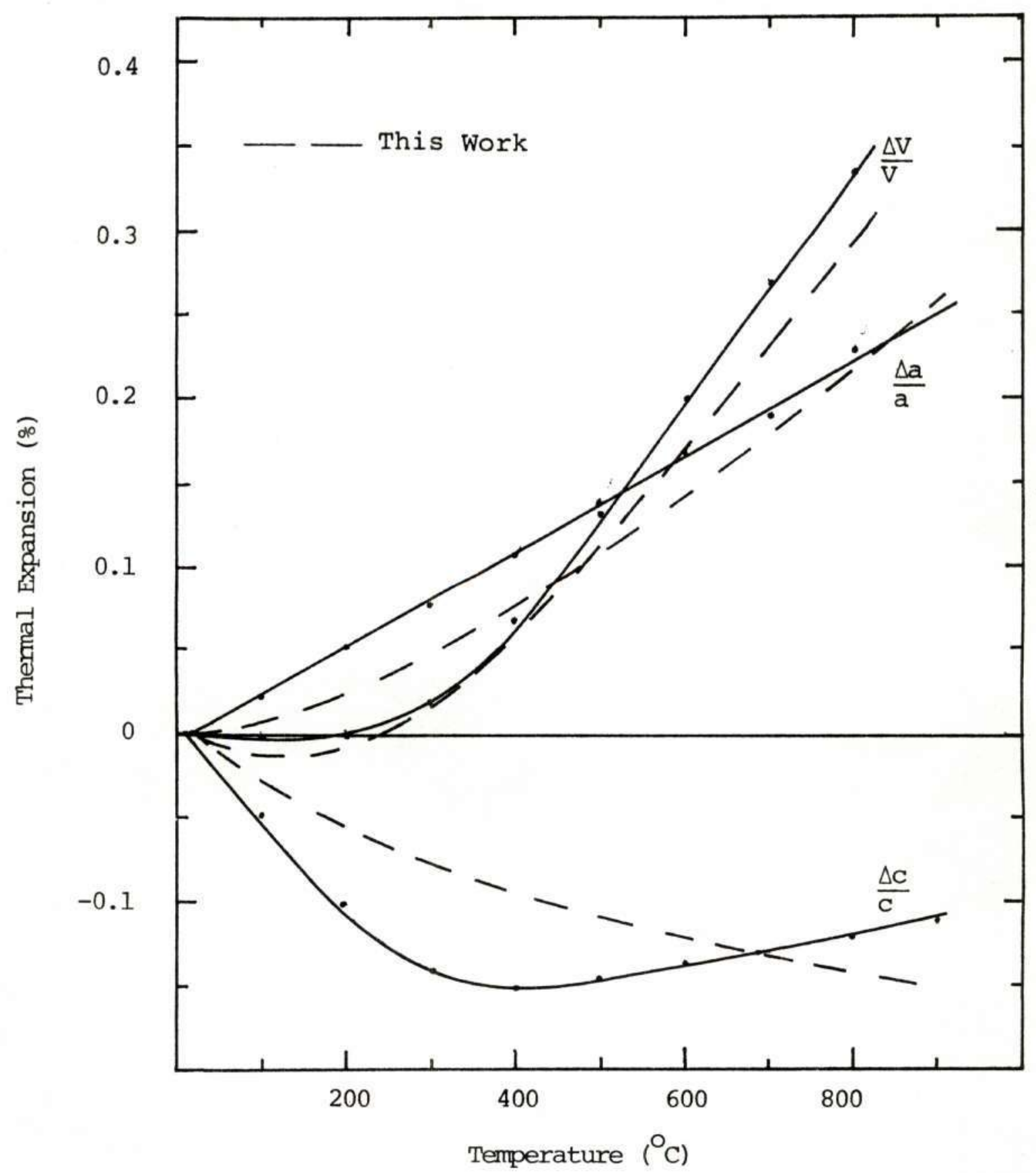

Fig. 7 Thermal Expansion of Cordierite: Axial Expansions and Unit Cell Volume Vs. Temperature (after Fisher et $\mathrm{al}^{20}$ ) 
Table 7. Thermal Contraction of Orthorhombic Cordierite: C-axis vs. Temperature

$$
\mathrm{L}_{\mathrm{O}}=0.1511 \mathrm{Cm}
$$

\begin{tabular}{ccccc}
\hline Fringe No. & Temp. & Measured Contraction of Contraction \\
$\mathrm{n}$ & & $\left({ }^{\circ} \mathrm{C}\right)$ & $\Delta \mathrm{L} \times 10^{-4} \mathrm{Cm}$ & $\Delta \mathrm{L} / \mathrm{L}_{\mathrm{o}}(\mathrm{8})$ \\
\hline 0 & 32 & $(35)$ & - & - \\
1 & 75 & $(80)$ & 0.273 & 0.018 \\
2 & 115 & $(135)$ & 0.546 & 0.036 \\
3 & 170 & $(190)$ & 0.819 & 0.054 \\
4 & 246 & $(280)$ & 1.092 & 0.072 \\
5 & 315 & $(380)$ & 1.365 & 0.090 \\
6 & 400 & $(483)$ & 1.638 & 0.108 \\
7 & 512 & $(620)$ & 1.911 & 0.126 \\
8 & 650 & $(820)$ & 2.184 & 0.145 \\
9 & 790 & 2.457 & 0.163 \\
\hline
\end{tabular}

( ): Hexagonal form 


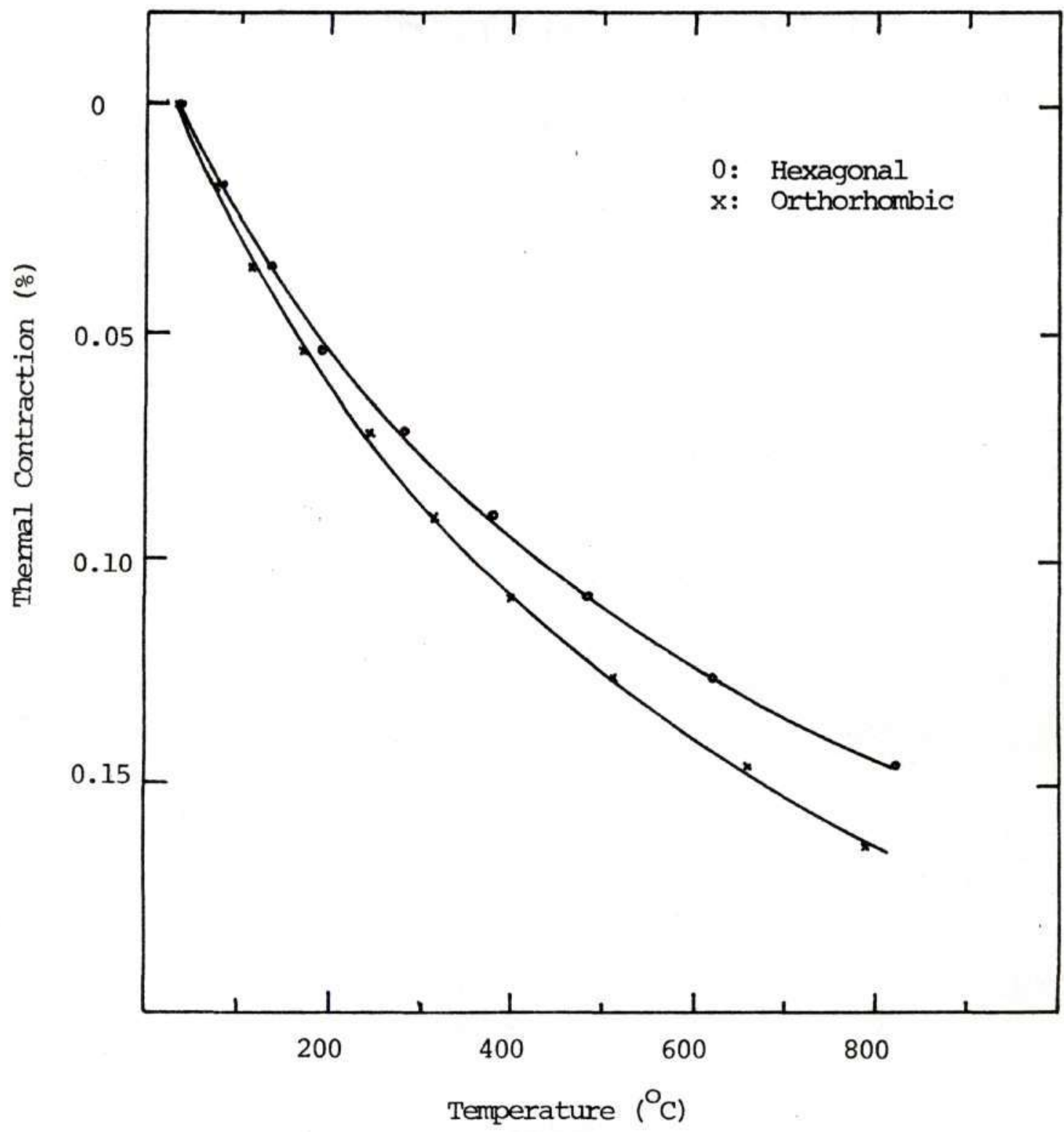

Fig. 8 Comparison of Thermal Contraction between Orthorhombic and Hexagonal Form of cordierite 
to predict the sense of the vector product of all angular and interatomic distance changes along the crystal axes. However, from the relation of structural deviation and corresponding thermal behavior in cordierite, perhaps it is possible to further understand the complex vector form and to explain the mechanism. 


\section{CHAPTER V}

\section{SUMMARY AND CONCLUSIONS}

1. Cordierite single crystals up to $6 \mathrm{~mm}$ long can be grown using $\mathrm{PbO}-\mathrm{V}_{2} \mathrm{O}_{5}$ as a flux by slow cooling from $1280^{\circ} \mathrm{C}$ to $950^{\circ} \mathrm{C}$ at $6^{\circ} \mathrm{C}$ per hour.

2. The solubility of cordierite in the solvent consisting of 71.2 wt $\mathrm{PbO}$ and 28.2 wt\% $\mathrm{V}_{2} \mathrm{O}_{5}$ was about 5 wt at $950^{\circ} \mathrm{C}$ and nearly 8 wto at $1280^{\circ} \mathrm{C}$.

3. The anisotropic axial and unit cell volume thermal expansion of the flux grown crystals (hexagonal form) were determined using a dilatation interferometer. The expansion along the a-axis is nearly linear within the temperature range studied while the contraction along c-axis is parabolic, similar to $\beta$-spodumene-silica solid solutions. The a-axis expansion was about $0.22 \%, 20^{\circ}$ to $800^{\circ} \mathrm{C}$. The c-axis contraction is about $0.14 \%, 20^{\circ} \mathrm{C}$ to $800^{\circ} \mathrm{C}$. The resulting thermal behavior of the cordierite unit cell is also similar to that of the $\beta$-spodumenesilica solid solutions.

4. The c-axis contraction of cordierite may increase as the structural deviation from hexagonal form increases. The c-axis contraction of the orthorhomibc form, obtained by heating the crystals at $1260^{\circ} \mathrm{C}$ for 165 hours, was $15 \%$ higher than that of the hexagonal form, over the range of $20^{\circ} \mathrm{C}$ to $850^{\circ} \mathrm{C}$. 


\section{CHAPTER VI \\ RECOMMENDATIONS}

For a better understanding of anisotropic thermal expansion mechanism of cordierite, and thermal behavior change during usage, additional studies are required on the effect of time and temperature on the structural deviation from hexagonal symmetry and on the structural mechanisms responsible for the thermal expansion anisotropy. 


\section{APPENDIX A}

Table 8. Semiquantitative Spectrochemical Analysis of the Cordierite Single Crystals

\begin{tabular}{|c|c|c|c|c|c|}
\hline Element & & 8 & Element & & 8 \\
\hline Aluminum & Al & 10 & Maganese & $\mathrm{Mn}$ & 0.001 \\
\hline Antimony & $\mathrm{Sb}$ & 0.005 & Mercury & $\mathrm{Hg}$ & \\
\hline Arsenic & As & 0.01 & Molybdenum & Mo & 0.005 \\
\hline Barium & $\mathrm{Ba}$ & & Nickel & $\mathrm{Ni}$ & 0.01 \\
\hline Beryllium & $\mathrm{Be}$ & 0.001 & Niobium & $\mathrm{Nb}$ & \\
\hline Bismuth & $\mathrm{Bi}$ & 0.003 & Phosphorus & $\mathrm{P}$ & 0.05 \\
\hline Baron & B & 0.005 & Silicon & $\mathrm{Si}$ & 10 \\
\hline Cadmium & $\mathrm{Cd}$ & 0.01 & Silver & $\mathrm{Ag}$ & 0.001 \\
\hline Calcium & $\mathrm{Ca}$ & 0.01 & Strontium & $\mathrm{Sr}$ & 0.05 \\
\hline Chromium & $\mathrm{Cr}$ & 0.001 & Tin & $\mathrm{Sn}$ & 0.005 \\
\hline Cobalt & Co & 0.01 & Titanium & $\mathrm{Ti}$ & 0.003 \\
\hline Copper & $\mathrm{Cu}$ & 0.001 & Vanadium & $\mathrm{V}$ & 0.1 \\
\hline Gallium & $\mathrm{Ga}$ & & Zinc & $\mathrm{Zn}$ & 0.0 \\
\hline Germanium & $\mathrm{Ge}$ & & Zirconium & $\mathrm{Zr}$ & 0.005 \\
\hline Indium & In & & Cesium & $\mathrm{Cs}$ & \\
\hline Iron & $\mathrm{Fe}$ & 0.02 & Lithium & $\mathrm{Li}$ & \\
\hline Lead & $\mathrm{Pb}$ & 0.05 & Potassium & $\mathrm{K}$ & \\
\hline \multirow[t]{2}{*}{ Magnesium } & $\mathrm{Mg}$ & 8.0 & Rubidium & $\mathrm{Rb}$ & \\
\hline & & & Sodium & $\mathrm{Na}$ & \\
\hline
\end{tabular}


APPENDIX B

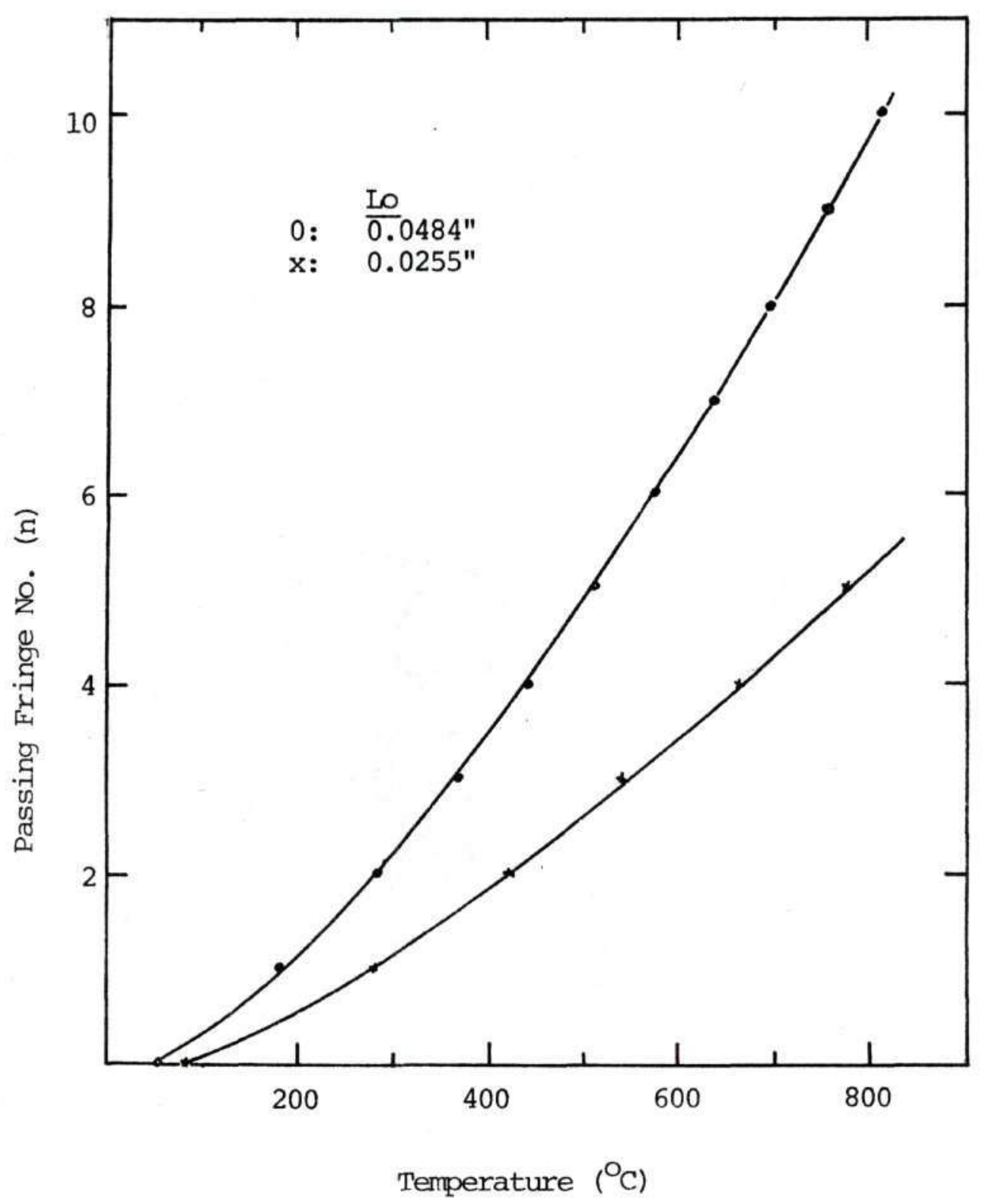

Fig. 9 Thermal Expansion of Cordierite Along the a-axis 


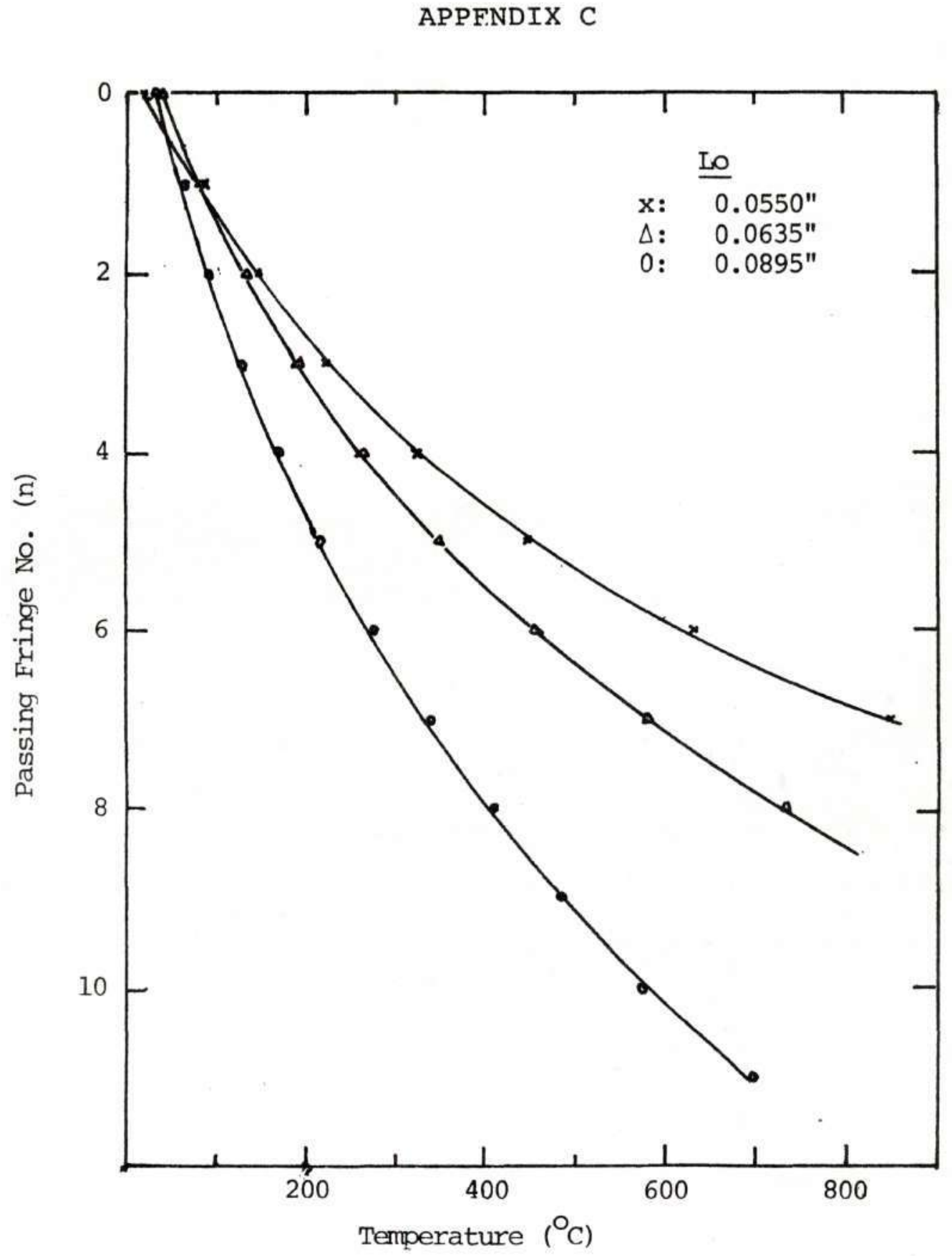

Fig. 10 Thermal Contraction of Cordierite Along C-axis 


\section{BIBLIOGRAPHY}

1. Lamar, R.S., "Development of Cordierite Bodies with Sierralite, a New Ceramic Material", J.Am. Ceram. Soc., 32 (2) 65 (1949).

2. Kroenert, W., Schwiete, H.S., and Suckow, A., "Die Bildung von Cordierit aus Talk, Kaolin und den oxiden im Dreistoffsystem $\mathrm{MgO}-\mathrm{Al}_{2} \mathrm{O}_{3}-\mathrm{SiO}_{2}, "$, Ber. DKG, 38, 420-425 (1964).

3. Thurnauer, H., "Properties and Uses of Technical Ceramics", Materials and Methods, 87 (1947).

4. Gossner, B. and F. Mussgnug, "Vergleichrde Roentgenographische Untersuchnug von Magnesiumsilikeaten," Neues Jahrb. Mineral., 58, 216-227 (1928).

5. Bragg, w.L., "The Structure of Silicates", Zeit. Krist., 74, 237-305 (1930).

6. Takane, K. and Takenchi, T., "The Crystal Structure of Cordierite", Jap. Assoc., Mineral Petrol. Econ. Geol.

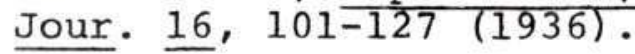

7. Bystroem, A., "The Crystal structure of Cordierite" Arkiv For Kemi, Mineralogi Och Geologi 15B (12) 1-5 (1942).

8. Karkhanavala, M.D., and F.A. Hummel, "The Polymorphism of Cordierite" J.Am.Cer.Soc. 36 (12) 389-392 (1953).

9. Miyashiro, A., T. Iiyama, M. Yamasaki and T. Miyashiro, "The Polymorphism of Cordierite and Indialite" Am. J.: Sci. 253 185-208 (1955).

10. Miyashiro Akio, "Cordierite-Indialite Relations", Am. J. Sci. 255 43-62 (1957)

11. Schreyer, W. and Schairer, J.F., "Compositions and Structural States of Anhydrous Mg-Cordierite: A ReInvestigation of the Central Part of the System MgO$\mathrm{Al}_{2} \mathrm{O}_{3}-\mathrm{SiO}_{2} "$, Journal of Petrology 2, Part 3, 324-406 (1961).

12. Sorrell, Charles A., "Reaction Sequence and Structural Changes in Cordierite Refractory", J.A. Ceram. Soc. 43 (7) $337(1960)$. 
13. Schreyer, W. and Yoder H.S., "The System Mg-Cordierite and Related Rocks", Mineral. Abstr., 101 271-342 (1964).

14. Langer, K. and Schreyer, W., "Infrared and Powder X-ray Diffraction Studies on the Polymorphism of Cordierite", The Am. Mineralogist, 54 (9) 1442 (1969).

15. Gibbs, G.V., "The Polymorphism of Cordierite I: The Crystal Structure of Low Cordierite", The Am. Mineralogist, 51 (7) 1068 (1966).

16. Hummel, F.A. and Reid, H.W., "Thermal Expansion of Some

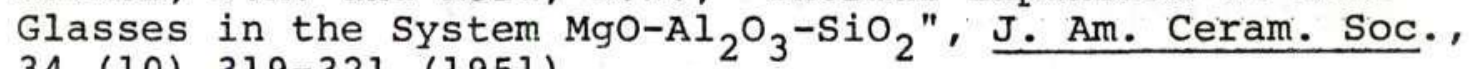
34 (10) 319-321 (1951).

17. Beals, R.J. and Cook, R.L., "Low-Expansion Cordierite Procelains", J. Am. Ceram. Soc., 35 (2) 53-57 (1952).

18. Von E. Gugel and $\mathrm{H}$. Vogel, "Grenzen der Anwendbarkeit bon Cordierithaltigen keramischen Werksoffen", Ber. Dtsch. Keram. Ges. 4l, H. 3, 191-204 (1964).

19. Sugiura Kozo and Kuroda Yasuhiro, "Thermal Expansion of Synthetic Cordierite", Yokyo, 63, 579-582 (1955).

20. Fischer, G.R. Evans, D.L. and Geiger, J.E., "The Crystal Lattice Thermal Expansion of Cordierite" (Submitted for Publication).

21. Hummel, F.A., "Observations on the Thermal Expansion of Crystalline and Glassy Substances", J.Am. Ceram. Soc., 33 (3) 102-107 (1950).

22. Gillery, F.H. and Bush, E.A. "Thermal Contraction of B-Eucryptite $\left(\mathrm{Li}, \mathrm{O}-\mathrm{Al}_{2} \mathrm{O}_{3}-2 \mathrm{SiO}_{2}\right)$ by $\mathrm{X}$-ray and Dilatometer Methods", J.Am. Ceram. Soc., 42 (4) 175-177 (1959).

23. Ostertag, W., Fischer, G.R. and Williams, J.P., "Thermal Expansion of Synthetic $\beta$-Spodumene and $\beta$-SpodumeneSilica Solid Solutions", J.Am. Ceram. Soc., 51 (11) 651-654 (1968).

24. Rogers, A.F., "Introduction to the Study of Minerals" 3rd Edition, (New York and London McGraw-Hill Book Company Inc., 1937), p. 490.

25. Laudise, R.A., "The Growth of Single Crystals", (Englewood Cliffs, New Jersey: Prentice Hall, Inc., 1970), P. 295 . 
26. Linares, R.C., Ballman, A.A., and VanUitert, L.G., Growth of Beryl Single Crystals for Microwave Application", J. App1. Phys. 33, 3209-3210 (1962).

27. Ballman, A.A., Linares, R.C., and Van Uitert, L.G., Growth of Beryl Crystals", U.S. Patent 3,234,135., Feb. 8, 1966.

28. Lefever, R.A., Chase, A.B., and Sobon, L.E., "Synthetic Emerald", Amer. Mineral, 47, 1450-1453 (1962).

29. Linares, R.C., "Growth of Beryl from Molten Salt Solution", Amer. Mineral., 52, 1554-1559 (1967).

30. Grodkiewicz, and Van Uitert, L.G., "Synthesis of Forsterite, Diopside, Akermanite, and Wollastonite from Molten $\mathrm{PbO}$ ", J. Am. Ceram. Soc., 46 (7) 356 (1963).

31. Garton, G., Smith S.H., and Wankly, B.M., "Crystal Growth From the Flux Systems $\mathrm{PbO}-\mathrm{V}_{2} \mathrm{O}_{5}$ and $\mathrm{Bi}_{2} \mathrm{O}_{3}-\mathrm{V}_{2} \mathrm{O}_{5}$ ", J. Crystal Growth 13/14 582-592 (1972).

32. Wood, D.L. and Nassau, J., "The Characterization of Beryl and Emerald by Visible and Infrared Absorption Spectroscopy", Amer. Mineral., 53, 777-800 (1968). 